\title{
PENERAPAN IoT (Internet of Things) DALAM PEMBUATAN TEMPAT SAMPAH PINTAR UNTUK RUMAH KOS
}

\author{
Dik Ajeng Ayutantri, Joseph Dedy Irawan, Suryo Adi Wibowo \\ Program Studi Teknik Informatika S1, Fakultas Teknologi Industri \\ Institut Teknologi Nasional Malang, Jalan Raya Karanglo km 2 Malang, Indonesia \\ 1718056@scholar.itn.ac.id
}

\begin{abstract}
ABSTRAK
Tempat sampah sangat penting terutama dalam kelengkapan untuk rumah kos. Ada beberapa rumah kos dimana menggunakan sistem pembuangan sampah dengan menyewa suatu karyawan untuk membuang sampah anak kos. Dalam hal ini, tempat sampah dapat dikembangkan menggunakan sistem teknologi Internet of Things (IoT) untuk memudahkan pekerjaan manusia dalam kesehariannya. Dari permasalahan tersebut, dapat dibuat teknologi IoT dengan suatu sistem yang dapat memberikan informasi mengenai isi kapasitas tempat sampah, sehingga memudahkan karyawan dalam pengecekan isi tempat sampah anak kos dengan system monitoring pada website. Selain itu, tempat sampah pintar dibekali dengan sensor kelembaban untuk mendeteksi apabila sampah yang lembab harus segera dibuang. Pengembangan sistem ini juga menambahkan sistem pendeteksi kebakaran sehingga apabila terdapat isi sampah yang mengandung gas seperti asap rokok, asap dari kertas yang dibakar, dan sejenisnya dapat diatasi segera dan meminimalisir kondisi kebakaran. Hasil pengujian terhadap Sensor Ultrasonik untuk mendeteksi isi kapasitas sampah menunjukkan selisih terbesar yaitu $2 \mathrm{~cm}$ dengan presentase error $0,2 \%$ dan selisih terkecil yaitu $0 \mathrm{~cm}$ dengan presentase error $0 \%$ dan rata-rata presentase error yaitu 0,13\%. Sensor DHT22 menunjukkan selisih terbesar yaitu 6 dengan presentase error 10\% dan selisih terkecil yaitu -2 dengan presentase error 2\% dan rata-rata presentase error yaitu 3\%, sedangkan Sensor MQ135 menunjukkan selisih terbesar $7 \mathrm{ppm}$ dengan presentase error 4,61\% dan selisih terkecil 1ppm dengan presentase error $0,57 \%$ dimana rata-rata presentase error yaitu $2,28 \%$.
\end{abstract}

\section{Kata kunci : tempat sampah pintar, system monitoring, ESP8266, embedded system, Internet of Things, Smart Home}

\section{PENDAHULUAN}

Sampah adalah bagian dari hidup dimana hal atau barang yang sudah tidak dipakai atau harus dibuang, tetapi bukan kegiatan biologis. Dalam berkegiatan, manusia memproduksi sampah. Semakin banyak sampah, perlu adanya pengolahan sampah kembali agar memiliki nilai yang lebih ekonomis dan tidak membahayakan lingkungan.

Kebersihkan merupakan hal yang tidak bisa kita hindari, tentunya kebersihan pun membawa dampak positif bagi lingkungan. Kebersihan dapat dilakukan dimanapun dan beberapa cakupan, baik pada seseorang, diri sendiri, maupun suatu lingkungan. Dalam kehidupan sehari-hari dalam rumah kos, membuang sampah adalah sebuah keharusan.

Rumah kos adalah sebuah tempat tinggal dengan sejumlah kamar yang disewakan dan dibayar dalam kurun waktu atau per periode tertentu. Salah satu tempat tinggal untuk banyak umat, yang bersifat sementara. Memudahkan bagi yang memiliki aktifitas beda kota dengan harga yang lebih terjangkau daripada tempat penginapan yang lainnya.

Dalam rumah kos, terdapat orang yang membersihkan sampah dalam tiap kamar. Posisi orang yang membersihkan sampah berada di lantai pertama, sedangkan posisi kamar anak kos berada di lantai 2. Untuk pengecekan dalam membuang sampah, dilakukan berdasarkan jumlah sampah yang terdapat dalam beberapa kamar kos. Semisal, apabila sampah hanya terdapat dalam 1 kamar, maka hari itu ia tidak membuang sampah. Apabila sampah terdapat dalam 2 atau lebih kamar, maka hari itu ia membuang sampah.

Masalah akan pengecekan sampah ini termasuk tidak efektif bagi orang yang membersihkan sampah kamar kos. Terutama orang yang membersihkan kamar kos ini cukup dibilang sudah berumur. Pengecekan sampah secara manual bukanlah hal yang bisa dikatakan mudah mengingat akan umur yang sudah ditempuhnya.

Adanya perkembangan teknologi sekarang dapat membantu pekerjaan manusia walau dalam hal sekecil ini. Pengecekan sampah melalui website dapat dipantau menggunakan Arduino Uno dan ESP8266 dengan wifi module. Tempat sampah dilengkapi dengan sensor ultrasonik (HC-SR04) dan komponen pelengkap lainnya sebagai alat bantu dalam memantau kondisi tempat sampah

\section{TINJAUAN PUSTAKA}

Prayitno dan kawan-kawan di tahun 2017 melakukan penelitian dengan judul "Sistem Monitoring Suhu, Kelembaban, dan Pengendali Penyiraman Tanaman Hidroponik menggunakan Blynk Android", bahwa tujuan penelitian ini adalah membuat sistem monitoring tanaman hidroponik yang bisa memantau kondisi lingkungan tanamannya meskipun berada dalam lokasi yang jauh dari lokasi penanaman. System monitoring yang dibuat oleh peneliti memiliki perbedaan dengan penulis, yaitu menggunakan platform website. Perbedaan lainnya ada dari segi penghubung jaringan dimana peneliti 
menggunakan ethernet shield, sedangkan penulis menggunakan ESP8266. [1]

Astutik pada tahun 2019 melakukan penelitian dengan judul "Aplikasi Telegram Untuk Sistem Monitoring Pada Smart Farming" memiliki tujuan untuk membuat sistem monitoring dan pemanfaatan aplikasi telegram dalam memberikan informasi data dalam sistem pertanian pintar. Rancangan berupa prototype untuk membuat prototype dalam lahan pertanian. Adapun perbedaan dengan sistem peneliti adalah platform yang digunakan. Peneliti menggunakan aplikasi Telegram sebagai media system monitoring, sedangkan penulis menggunakan website dan termasuk kedalam smart home. [2]

Rahardja dan kawan-kawan tahun 2018 peneliti dengan judul "Monitoring Kinerja User Akuntan Menggunakan Dashboard pada Web Based Accounting Online di Perguruan Tinggi”. Tujuan penelitian ini adalah untuk memantu kinerja user akuntan yang menampilkan hal-hal yang terjadi pada akun milik instansi yang meliputi tindakan-tindakan user. Adapun persamaan dari penelitian ini yaitu sama-sama membuat aplikasi monitoring, tetapi terdapat persamaan pada media yang digunakan dalam system monitoring. Peneliti dan penulis sama sama menggunakan system monitoring dengan platform website. [3]

Susanti dan kawan-kawan tahun 2016 pada penelitian dengan judul "Pengembangan Sistem Pemantau Dan Pengendali Kendaraan Menggunakan Raspberry Pi Dan Firebase". Tujuan penelitian ini adalah untuk mengatasi permasalahan pemantauan dan pengendalian terhadap kendaraan. Cara kerjanya menggunakan akuisisi data posisi koordinat dari satelit GPS pada kendaraan dimana datanya akan dikirimkan ke web secara realtime. Pada peneliti ini ia menggunakan Server Firebase serta menggunakan microcontroller Raspberry $P i$ sebagai media penghubung dalam system monitoring. Sedangkan penulis menggunakan ESP8266 sebagai media penghubung system monitoring dalam website menggunakan database MySQL [4]

Waker di tahun 2019 pada penelitian dengan judul "Perencanaan Pengelolaan Sampah Kampus I Institur Teknologi Nasional Malang”. Tujuan pada penelitian ini adalah untuk mengkaji lebih lanjut mengenai pengelolaan sampah di kawasan Kampus I Institut Teknologi Nasional Malang. Penelitian ini lebih mendalam mengenai isi data yang dibutuhkan dalam menunjang sistem pengelolaan sampah seperti timbulan, komposisi, dan karakteristik sampah. [5]

Putra dan kawan-kawan pada tahun 2020 penelitian dengan judul "Penerapan Sistem Monitoring Healthy Smart Home Dengan Early Warning System" tujuan penelitian ini adalah menerapkan Internet Of Things kedalam smart home yang berisi alat rumah tangga yang terhubung dengan early warning system. Adapun persamaan dari penelitian ini yaitu sama sama membuat suatu komposisi yang berhubungan dengan smart home.
Yang menjadi perbedaan dengan sistem yang dibuat oleh penulis adalah monitoring alat rumah tangga, sedangkan penulis monitoring isi kapasitas tempat sampah. [6]

\subsection{Smart Home}

Smart Home merupakan sistem yang mengatur beberapa perangkat rumah tangga yang terintegrasi dengan sistem komputer maupun mobile. Kurnianto dan kawan-kawan tahun 2016 mengungkapkan bahwa, smart home memiliki manfaat dalam memberikan kemudahan dalam pekerjaan manusia, seperti mengendalikan lampu ruangan, televisi, hingga pemantauan isi kapasitas tempat sampah. Pengguna dapat memantau perangkat rumah tangga melalui konektifitas wifi, bluetooth, maupun internet. [7]

\subsection{IoT (Internet of Things)}

Ungkapan dari Hardyanto pada tahun 2017 bahwa Internet of Things (IoT) adalah benda perangkat fisik dimana dapat saling memberikan informasi, operator layanan ataupun perangkat lainnya yang dapat dikontrol maupun dipantau dengan sistem untuk memberikan kemudahan yang lebih baik. Perangkat fisik yang biasanya pada Internet of Things adalah hardware yang tertanam (embedded) dengan elektronik, perangkat lunak, sensor dan juga konektivitas. [8]

\subsection{Arduino Uno}

Menurut Kustanti dan kawan-kawan tahun 2016, Arduino UNO merupakan board mikrokontroler berdasarkan ATmega328. Arduino UNO terdapat 14 pin digital yaitu input dan output, 6 pin sebagai output PWM. 6 pin sebagai input analog, osilator crystal $16 \mathrm{MHz}$, port koneksi USB, power jack, ICSP header, dan tombol reset. [9]

\subsection{ESP8266}

Modul ESP8266 adalah modul dilengkapi fitur wi-fi dapat digunakan secara standalone (sendirian) maupun dengan microcontroller tambahan untuk kontrolnya. Menurut Putra dan teman-teman pada tahun 2020 modul ESP8266 adalah low-cost Wi-Fi dengan penggunaan TCP/IP. Tahun 2014, AI-Thinker manufaktur mengeluarkan modul ESP-01, dimana menggunakan AT-Command untuk konfigurasinya dengan bantuan ESP8266. [10]

\subsection{Sensor Ultrasonik (HC-SR04)}

Sensor ultrasonik adalah sebuah sensor yang berfungsi untuk mengubah besaran fisis (bunyi) menjadi besaran listrik dan sebaliknya. Ungkapan dari Yudha dan Sani tahun 2020, cara kerja ultrasonik menggunakan pantulan gelombang suara untuk menafsirkan eksistensi (jarak) suatu benda dengan frekuensi tertentu. Berfungsi sebagai pengirim, penerima, dan pengontrol. Sensor ultrasoik untuk 
mengukur jarak benda dari $2 \mathrm{~cm}$ hingga $4 \mathrm{~m}$ dengan akurasi $3 \mathrm{~mm}$. [11]

\subsection{Buzzer}

Buzzer merupakan sebuah komponen elektronika yang berfungsi untuk mengubah energi listrik menjadi getaran suara. Saing dan Hernawan tahun 2019 mengungkapkan bahwa, buzzer terdiri dari kumparan yang dialiri oleh arus lalu menjadi elektromagnetik, yang dimana kumparan tersebut tertarik ke dalam atau keluar tergantung arah arus dan polaritas magnetnya. Setiap gerakan bolak-balik kumparan yang terpasang pada diafragma akan membuat udara bergetar sehingga menghasilkan suara.[12]

\subsection{Sensor Pyroelectric Infrared}

Sensor PIR adalah sensor yang peka terhadap radiasi infrared-jauh (far-infrared) dalam rentang 4 $\mu \mathrm{m}$ hingga $20 \mu \mathrm{m}$, dimana rentang panjang gelombang tersebut dipancarkan oleh tubuh manusia. Menurut Perdana tahun 2019 sensor PIR pada dasarnya terbuat dari sensor pyroelectric yang bisa mendeteksi tingkatan radiasi infrared. Alasan khusus digunakan elemen pyroelectric adalah untuk mendeteksi gerak objek karena elemen sensor ini sederhana, relatif murah dan memiliki responsitivitas tinggi, dan rentang dinamik yang lebar. [13]

\subsection{Sensor DHT22}

Menurut Budi dan Pramudya (2017), sensor DHT22 adalah sensor dengan kalibrasi sinyal digital yang mampu memberikan informasi suhu dan kelembaban udara. Sensor ini tergolong komponen yang memiliki tingkat stabilitas yang sangat baik serta fitur kalibrasi yang dengan nilai perbedaan galatnya itu sekitar 18\%. Prinsip kerjanya adalah memanfaatkan perubahan kapasitif perubahan posisi bahan dielektrik diantara kedua keping, pergeseran posisi salah satu keping dan luas keping yang berhadapan langsung. [14]

\subsection{Sensor MQ135}

Menurut Rosa dkk (2020), sensor MQ135 merupakan gas sensor. Sensor MQ135 punya nilai resistansi Rs yang akan berubah jika ada gas dan juga memiliki pemanas (heater) untuk membersihkan ruangan dari kontaminasi udara luar. Sensor kualitas udara MQ135 adalah sensor yang mendeteksi NH3, NOx, alcohol, Benzene, smoke, CO2, dan asap/gasgas lainnya di udara. [15]

\subsection{Motor Servo}

Prayitno dan kawan-kawan tahun 2017 mengungkapkan bahwa, komponen yang digunakan yaitu motor servo standar 1800 dengan defleksi masing-masing sudut mencapai 900 sehingga total defleksi sudut dari kanan - tengah - kiri adalah 1800 . Cara kerja motor servo dikendalikan pulsa kurang lebih $\pm 20 \mathrm{~ms}$. Pulsa ini lah yang mengatur cara kerja motor servo menggunakan sudut. [1]

\subsection{LED RGB}

Menurut Hartika dan kawan-kawan tahun 2017, LED atau kepanjangan dari Light Emitting Diode, dimana memiliki dua kutub yaitu anoda dan katoda. LED menyala jika kondisi dua kutub ini saling mengalir. Terdapat 3 warna, yaitu red (merah), green (hijau), dan blue (biru). Bisa juga dengan menggabungkan beberapa warna sehingga menghasilkan warna baru. Terdapat warna dengan kondisi RGB (red, green, blue), setiap bagiannya dapat bervariasi dari nol sampai nilai maksimum yang ditetapkan [16].

\section{METODOLOGI PENELITIAN}

Penelitian ini akan membahas mengenai perancangan dan pembuatan alat monitoring tempat sampah pintar berbasis website.

\subsection{Diagram Blok Sistem}

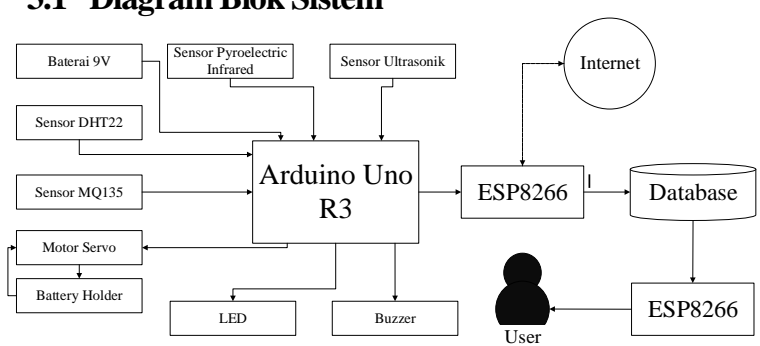

Gambar 1. Diagram Blok Sistem

Gambar diatas menjelaskan bahwa sistem ini menggunakan minimun system Arduino UNO, dimana Arduino UNO digunakan untuk monitoring beberapa komponen yang masuk (input) seperti, Sensor DHT22, sensor Pyroelectric Infrared, sensor MQ135, dan sensor ultrasonik. Sensor ultrasonik akan mengirimkan data isi kapasitas sampah berdasarkan tinggi benda ke Arduino Uno. Sensor Pyroelectric Infrared untuk mengecek apakah ada objek di depan tempat sampah. Dibantu dengan sensor DHT22 untuk mengecek kelembaban pada bagian dalam tempat sampah, dan sensor MQ135 untuk pengecekan adanya asap dari suatu benda yang terbakar. Apabila terdeteksinya semua kondisi, maka komponen seperti buzzer dan LED akan menyala, namun memiliki output yang berbeda. Selanjutnya, melalui Modul ESP8266 data akan disimpan dalam database, lalu ditampilkan lewat browser monitoring. 


\subsection{Struktur Menu Website}

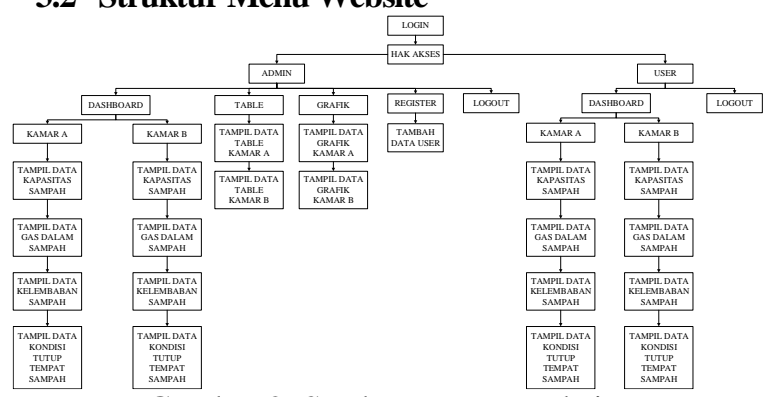

Gambar 2. Struktur Menu Website

Pada tampilan awal terdapat halaman login. Dimana setelah login, akan masuk sesuai hak akses dari akun tersebut. Jika login dengan akun admin, maka ada 4 pilihan menu dimana ada dashboard, table, grafik, register, dan logout. Pada dashboard terdapat tampilan data pada kamar A dan kamar B yang terdiri dari tampil data kapasitas sampah, gas dalam sampah, kelembaban sampah, dan kondisi tutup tempat sampah.

Pada halaman table, terdapat halaman dimana menampilkan semua kondisi sampah pada kamar A dan kamar B. Pada halaman grafik juga menampilkan semua kondisi sampah dalam bentuk line diagram dengan sistem time series pada kamar A dan kamar B. Pada halaman register untuk membuat akun user yang baru. Halaman logout berfungsi untuk keluar dari akun admin.

Pada kondisi pada akun user, hanya terdapat halaman dashboard dan logout. Tampilan pada dashboard sama persis dengan pada akun admin, dan begitu juga dengan logout.

\subsection{Alokasi Pin}

Alokasi pin untuk monitoring tempat sampah pintar berbasis website antara lain :

Tabel 2. Alokasi Pin

\begin{tabular}{|c|c|c|c|c|}
\hline No & Alat & Tipe & Pin & Tegangan \\
\hline \multirow[t]{2}{*}{1} & \multirow{2}{*}{$\begin{array}{l}\text { Sensor } \\
\text { ultrasonic }\end{array}$} & Echo & 6 & \multirow[t]{2}{*}{$5 \mathrm{~V}$} \\
\hline & & Trig & 5 & \\
\hline 2 & Buzzer & Digital & 9 & $5 \mathrm{~V}$ \\
\hline 3 & $\begin{array}{l}\text { Sensor } \\
\text { MQ135 }\end{array}$ & Analog & A0 & $5 \mathrm{~V}$ \\
\hline 4 & $\begin{array}{l}\text { Sensor } \\
\text { Infrared }\end{array}$ & Digital & 10 & $5 \mathrm{~V}$ \\
\hline \multirow[t]{2}{*}{5} & \multirow[t]{2}{*}{ ESP8266 } & RX & 4 & \multirow[t]{2}{*}{$5 \mathrm{~V}$} \\
\hline & & TX & 3 & \\
\hline \multirow[t]{3}{*}{6} & \multirow[t]{3}{*}{ LED RGB } & Red Pin & 13 & \multirow[t]{3}{*}{$5 \mathrm{~V}$} \\
\hline & & Green Pin & 12 & \\
\hline & & Blue Pin & 11 & \\
\hline 7 & $\begin{array}{l}\text { Motor } \\
\text { Servo }\end{array}$ & Digital & 2 & $12 \mathrm{~V}$ \\
\hline 8 & DHT22 & Digital & 7 & $5 \mathrm{~V}$ \\
\hline
\end{tabular}

\subsection{Desain Arsitektur Sistem}

Desain arsitektur metode menjelaskan alur dari tempat sampah pintar berbasis website. Flowchart metode bisa dilihat pada Gambar 3.

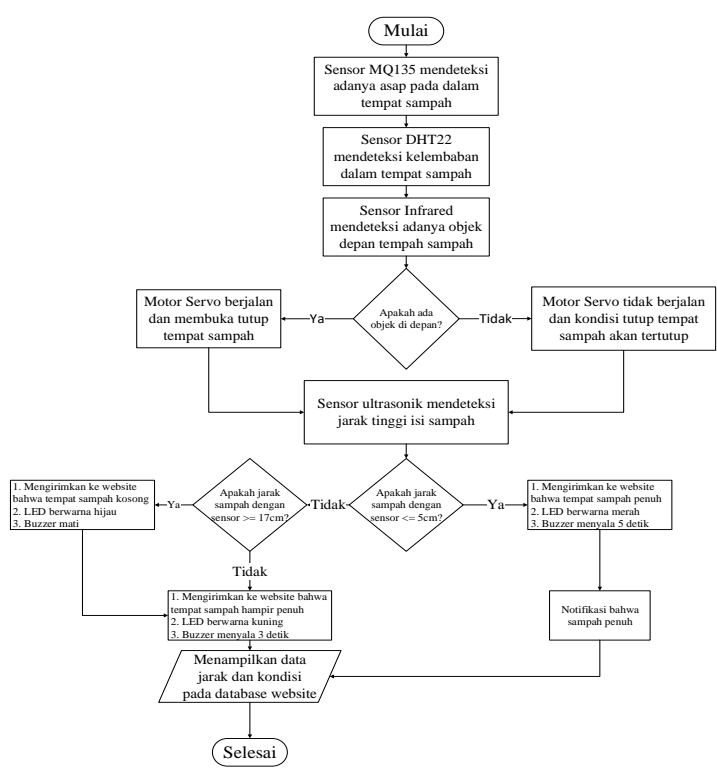

Gambar 3. Desain Arsitektur Sistem

\section{HASIL DAN PEMBAHASAN}

\subsection{Pengujian Sensor Ultrasonik HC-SR04}

Pengujian Sensor Ultrasonik untuk mendeteksi isi kapasitas tempat sampah dilakukan dengan cara membandingkan hasil output deteksi dari sensor Ultrasonik HC-SR04 dengan penggaris yang hasilnya dapat dilihat pada Tabel 3 berikut ini.

Tabel 3. Pengujian Sensor Ultrasonik

\begin{tabular}{|c|c|c|c|c|c|c|}
\hline $\begin{array}{l}\mathbf{N} \\
\mathbf{0}\end{array}$ & $\begin{array}{l}\text { Nama } \\
\text { Objek }\end{array}$ & $\begin{array}{c}\text { Posis } \\
\quad \text { i }\end{array}$ & $\begin{array}{l}\text { Peng } \\
\text { garis }\end{array}$ & $\begin{array}{c}\text { Sensor } \\
\text { Ultraso } \\
\text { nik }\end{array}$ & $\begin{array}{c}\text { Selis } \\
\text { ih }\end{array}$ & $\begin{array}{c}\text { Present } \\
\text { ase } \\
\text { Error }\end{array}$ \\
\hline 1 & $\begin{array}{c}\text { Tissue } \\
250 \\
\text { sheets }\end{array}$ & $\begin{array}{l}\text { Berd } \\
\text { iri }\end{array}$ & $\begin{array}{l}19 \\
\mathrm{~cm}\end{array}$ & $18 \mathrm{~cm}$ & $1 \mathrm{~cm}$ & $0,05 \%$ \\
\hline 2 & $\begin{array}{l}\text { Isolasi } \\
\text { Besar }\end{array}$ & $\begin{array}{c}\text { Berd } \\
\text { iri }\end{array}$ & $\begin{array}{l}9,5 \\
\mathrm{~cm}\end{array}$ & $8 \mathrm{~cm}$ & $\begin{array}{l}1,5 \\
\mathrm{~cm}\end{array}$ & $0,16 \%$ \\
\hline 3 & $\begin{array}{c}\text { Botol } \\
\text { Minuman } \\
\text { 1L }\end{array}$ & $\begin{array}{c}\text { Miri } \\
\text { ng }\end{array}$ & $\begin{array}{l}10 \\
\mathrm{~cm}\end{array}$ & $8 \mathrm{~cm}$ & $2 \mathrm{~cm}$ & $0,20 \%$ \\
\hline 4 & $\begin{array}{c}\text { Botol } \\
\text { madurasa }\end{array}$ & $\begin{array}{c}\text { Berd } \\
\text { iri }\end{array}$ & $\begin{array}{l}10 \\
\mathrm{~cm}\end{array}$ & $10 \mathrm{~cm}$ & $0 \mathrm{~cm}$ & $0 \%$ \\
\hline 5 & $\begin{array}{c}\text { kapas } \\
\text { selection } \\
175 \mathrm{pcs}\end{array}$ & $\begin{array}{c}\text { Miri } \\
\text { ng }\end{array}$ & $8 \mathrm{~cm}$ & $6 \mathrm{~cm}$ & $2 \mathrm{~cm}$ & $0,25 \%$ \\
\hline 6 & $\begin{array}{c}\text { Botol } \\
\text { aqua } \\
600 \mathrm{ml} \\
\text { ditekuk }\end{array}$ & $\begin{array}{c}\text { Miri } \\
\text { ng }\end{array}$ & $7 \mathrm{~cm}$ & $6 \mathrm{~cm}$ & $1 \mathrm{~cm}$ & $0,14 \%$ \\
\hline 7 & $\begin{array}{c}\text { Botol air } \\
\text { indomaret } \\
1,5 \mathrm{~L} \\
\text { ditekuk }\end{array}$ & $\begin{array}{l}\text { Berd } \\
\text { iri }\end{array}$ & $\begin{array}{l}20 \\
\mathrm{~cm}\end{array}$ & $18,5 \mathrm{~cm}$ & $\begin{array}{l}1,5 \\
\mathrm{~cm}\end{array}$ & $0,08 \%$ \\
\hline 8 & $\begin{array}{c}\text { Kresek } \\
\text { kecil } \\
\text { tanpa } \\
\text { dilipat }\end{array}$ & $\begin{array}{c}\text { Berd } \\
\text { iri }\end{array}$ & $\begin{array}{l}17 \\
\mathrm{~cm}\end{array}$ & $16 \mathrm{~cm}$ & $1 \mathrm{~cm}$ & $0,06 \%$ \\
\hline 9 & $\begin{array}{c}\text { Kertas A4 } \\
\text { diuntal }\end{array}$ & $\begin{array}{c}\text { Berd } \\
\text { iri }\end{array}$ & $\begin{array}{l}6,5 \\
\mathrm{~cm}\end{array}$ & $5 \mathrm{~cm}$ & $\begin{array}{l}1,5 \\
\mathrm{~cm}\end{array}$ & $0,23 \%$ \\
\hline $\begin{array}{l}1 \\
0\end{array}$ & $\begin{array}{c}\text { Tissue } \\
\text { digulung } \\
5 \text { lembar }\end{array}$ & $\begin{array}{c}\text { Berd } \\
\text { iri }\end{array}$ & $6 \mathrm{~cm}$ & $5 \mathrm{~cm}$ & $1 \mathrm{~cm}$ & $0,17 \%$ \\
\hline \multicolumn{6}{|c|}{ Rata - rata presentase error } & $\mathbf{0 , 1 3 \%}$ \\
\hline
\end{tabular}


Rumus pengujian sebagai berikut :

$\mid(($ Nilai Penggaris - Nilai Sensor) / Nilai Penggaris $) \mid *$ $100 \%$

Dari hasil pengujian pada Tabel 3 bisa diamati bahwa selisih terbesar pada pengujian yaitu sebesar $2 \mathrm{~cm}$ dan selisih terkecil yaitu $0 \mathrm{~cm}$ dengan rata-rata persentase error sebesar $0,13 \%$.

\subsection{Pengujian Terhadap Sensor DHT22}

Pengujian Sensor DHT22 untuk mendeteksi kelembaban dalam tempat sampah yang dilakukan dengan cara membandingkan hasil output deteksi dari sensor DHT22 dengan Hygrometer yang hasilnya dapat dilihat pada Tabel 4 berikut ini.

Tabel 4. Pengujian Sensor DHT22

\begin{tabular}{|c|c|c|c|c|}
\hline No & $\begin{array}{c}\text { DHT22 } \\
\text { (Kelembaban) }\end{array}$ & Hygrometer & Selisih & $\begin{array}{c}\text { Presentase } \\
\text { Error }\end{array}$ \\
\hline 1 & 66 & 66 & 0 & $0 \%$ \\
\hline 2 & 79 & 81 & -2 & $2 \%$ \\
\hline 3 & 71 & 73 & -2 & $3 \%$ \\
\hline 4 & 70 & 69 & 1 & $1 \%$ \\
\hline 5 & 67 & 61 & 6 & $10 \%$ \\
\hline \multicolumn{4}{|r}{} \\
\hline
\end{tabular}

Rumus pengujian sebagai berikut :

| (Nilai Hygrometer / Nilai Sensor) / Nilai Hygrometer |* $100 \%$

Dari hasil pengujian pada Tabel 4 bisa diamati bahwa selisih terbesar pada pengujian yaitu sebesar 6 dan selisih terkecil yaitu -2 dengan rata-rata persentase error sebesar 3\%. Dari hasil analisis pengujian hal ini dikarenakan karakteristik sensor DHT22 ketika mendeteksi kelembaban diatas 70 tingkat keakuratan mulai berkurang.

\subsection{Pengujian Terhadap Sensor MQ135}

Pengujian Sensor MQ135 untuk mendeteksi kebakaran dalam tempat sampah yang dilakukan dengan cara membandingkan hasil output deteksi dari sensor MQ135 dengan Gas Detector.

Tabel 5. Pengujian Sensor MQ135

\begin{tabular}{|c|c|c|c|c|}
\hline No & MQ135 & $\begin{array}{c}\text { Combustible } \\
\text { Gas Detector } \\
\mathbf{6 0 2}\end{array}$ & Selisih & Presentase Error \\
\hline 1 & 206 & 200 & 6 & $3,00 \%$ \\
\hline 2 & 176 & 175 & 1 & $0,57 \%$ \\
\hline 3 & 159 & 152 & 7 & $4,61 \%$ \\
\hline 4 & 168 & 167 & 1 & $0,60 \%$ \\
\hline 5 & 157 & 153 & 4 & $2,61 \%$ \\
\hline \multicolumn{4}{|c|}{ Rata-rata presentase error } & $\mathbf{2 , 2 8 \%}$ \\
\hline
\end{tabular}

Rumus pengujian sebagai berikut :

| (Nilai Gas Detector/Nilai Sensor)/Nilai Gas Detector |* $100 \%$

Dari hasil pengujian pada Tabel 5 bisa diamati bahwa selisih terbesar pada pengujian yaitu sebesar 7 dan selisih terkecil yaitu 1 dengan rata-rata persentase error sebesar $2,28 \%$.

\subsection{Skenario Pengujian Sensor Infrared}

Skenario pengujian Sensor Infrared untuk mendeteksi adanya objek depan tempat sampah yang dilakukan dengan menggunakan penggaris sebagai penguji, hal ini untuk melihat respon output dari tempat sampah yang hasilnya dapat dilihat pada Tabel 6 berikut ini.

Tabel 6. Skenario Pengujian Sensor Infrared

\begin{tabular}{|c|c|c|c|}
\hline No & $\begin{array}{c}\text { Nilai } \\
\text { Penggaris }\end{array}$ & $\begin{array}{c}\text { Nilai Sensor } \\
\text { Infrared }\end{array}$ & $\begin{array}{c}\text { Respon } \\
\text { Tempat } \\
\text { Sampah }\end{array}$ \\
\hline 1 & $2 \mathrm{~cm}$ & 0 & Tertutup \\
\hline 2 & $4 \mathrm{~cm}$ & 1 & Terbuka \\
\hline 3 & $6 \mathrm{~cm}$ & 1 & Terbuka \\
\hline 4 & $10 \mathrm{~cm}$ & 1 & Terbuka \\
\hline 5 & $12 \mathrm{~cm}$ & 1 & Terbuka \\
\hline 6 & $16 \mathrm{~cm}$ & 1 & Terbuka \\
\hline 7 & $17 \mathrm{~cm}$ & 1 & Terbuka \\
\hline 8 & $19 \mathrm{~cm}$ & 0 & Tertutup \\
\hline 9 & $23 \mathrm{~cm}$ & 0 & Tertutup \\
\hline 10 & $30 \mathrm{~cm}$ & 0 & Tertutup \\
\hline
\end{tabular}

Dari hasil pengujian pada Tabel 6 bisa diamati bahwa sensor infrared dapat mendeteksi objek pada range $4 \mathrm{~cm}$ sampai $17 \mathrm{~cm}$ dimana kondisi tutup tempat sampah akan terbuka.

\subsection{Skenario Pengujian Sensor Ultrasonik}

Skenario pengujian Sensor Ultrasonik untuk mendeteksi isi kapasitas tempat sampah berdasarkan tinggi sampah yang dilakukan dengan menggunakan penggaris sebagai penguji, hal ini untuk melihat respon output dari tempat sampah yang hasilnya dapat dilihat pada Tabel 7 berikut ini.

Tabel 7. Skenario Pengujian Sensor Ultrasonik

\begin{tabular}{|c|c|c|c|c|c|}
\hline $\begin{array}{l}\mathbf{N} \\
\mathbf{o}\end{array}$ & $\begin{array}{l}\text { Nama } \\
\text { Objek }\end{array}$ & Posisi & $\begin{array}{c}\text { Penggar } \\
\text { is }\end{array}$ & $\begin{array}{c}\text { Nilai } \\
\text { Sensor } \\
\text { Ultrasoni } \\
\text { k }\end{array}$ & $\begin{array}{l}\text { Respon } \\
\text { Tempat } \\
\text { Sampah }\end{array}$ \\
\hline 1 & $\begin{array}{l}\text { Tissue } \\
250 \\
\text { sheets }\end{array}$ & $\begin{array}{l}\text { Berdi } \\
\text { ri }\end{array}$ & $19 \mathrm{~cm}$ & $18 \mathrm{~cm}$ & $\begin{array}{c}\text { LED merah } \\
\text { (penuh), } \\
\text { Buzzer } \\
\text { menyala }\end{array}$ \\
\hline 2 & $\begin{array}{l}\text { Isolasi } \\
\text { Besar }\end{array}$ & $\begin{array}{l}\text { Berdi } \\
\text { ri }\end{array}$ & $9,5 \mathrm{~cm}$ & $8 \mathrm{~cm}$ & $\begin{array}{l}\text { LED kuning } \\
\text { (hampir } \\
\text { penuh) }\end{array}$ \\
\hline 3 & $\begin{array}{c}\text { Botol } \\
\text { Minuma } \\
\text { n 1L }\end{array}$ & $\begin{array}{l}\text { Mirin } \\
\mathrm{g}\end{array}$ & $10 \mathrm{~cm}$ & $8 \mathrm{~cm}$ & $\begin{array}{l}\text { LED kuning } \\
\text { (hampir } \\
\text { penuh) }\end{array}$ \\
\hline 4 & $\begin{array}{c}\text { Botol } \\
\text { maduras } \\
\mathrm{a} \\
\end{array}$ & $\begin{array}{l}\text { Berdi } \\
\text { ri }\end{array}$ & $10 \mathrm{~cm}$ & $10 \mathrm{~cm}$ & $\begin{array}{c}\text { LED kuning } \\
\text { (hampir } \\
\text { penuh) }\end{array}$ \\
\hline 5 & $\begin{array}{c}\text { aqua } \\
\text { 600ml } \\
\text { ditekuk }\end{array}$ & $\begin{array}{l}\text { Mirin } \\
\mathrm{g}\end{array}$ & $7 \mathrm{~cm}$ & $6 \mathrm{~cm}$ & $\begin{array}{l}\text { LED kuning } \\
\text { (hampir } \\
\text { penuh) }\end{array}$ \\
\hline 6 & $\begin{array}{c}\text { Botol air } \\
\text { indomar } \\
\text { et } 1,5 \mathrm{~L} \\
\text { ditekuk }\end{array}$ & $\begin{array}{l}\text { Berdi } \\
\text { ri }\end{array}$ & $20 \mathrm{~cm}$ & $18,5 \mathrm{~cm}$ & $\begin{array}{c}\text { LED merah } \\
\text { (penuh), } \\
\text { Buzzer } \\
\text { menyala }\end{array}$ \\
\hline 7 & $\begin{array}{c}\text { Kresek } \\
\text { kecil } \\
\text { tanpa } \\
\text { dilipat }\end{array}$ & $\begin{array}{l}\text { Berdi } \\
\text { ri }\end{array}$ & $17 \mathrm{~cm}$ & $60 \mathrm{~cm}$ & $\begin{array}{l}\text { LED kuning } \\
\text { (hampir } \\
\text { penuh) }\end{array}$ \\
\hline
\end{tabular}




\begin{tabular}{|c|c|c|c|c|c|}
8 & $\begin{array}{c}\text { Kertas } \\
\text { A4 } \\
\text { diuntal }\end{array}$ & $\begin{array}{c}\text { Berdi } \\
\text { ri }\end{array}$ & $6,5 \mathrm{~cm}$ & $5 \mathrm{~cm}$ & $\begin{array}{c}\text { LED hijau } \\
\text { (kosong) }\end{array}$ \\
\hline 9 & $\begin{array}{c}\text { Tissue } \\
\text { digulung }\end{array}$ & $\begin{array}{c}\text { Berdi } \\
\text { ri }\end{array}$ & $6 \mathrm{~cm}$ & $5 \mathrm{~cm}$ & $\begin{array}{c}\text { LED hijau } \\
\text { (kosong) }\end{array}$ \\
\hline 10 & $\begin{array}{c}\text { kapas } \\
\text { selection } \\
175 p c s\end{array}$ & $\begin{array}{c}\text { Mirin } \\
\mathrm{g}\end{array}$ & $8 \mathrm{~cm}$ & $6 \mathrm{~cm}$ & $\begin{array}{c}\text { LED kuning } \\
\text { (hampir } \\
\text { penuh) }\end{array}$ \\
\hline
\end{tabular}

Dari hasil pengujian pada Tabel 7 bisa diamati bahwa tempat sampah akan merespon apabila ukuran sampah dibawah $5 \mathrm{~cm}$, maka akan terdeteksi penuh dengan kondisi LED berwarna merah dan buzzer menyala. Apabila ukuran sampah ada diantara $6 \mathrm{~cm}$ hingga $17 \mathrm{~cm}$, maka akan terdeteksi sebagai hampir penuh dengan kondisi LED berwarna kuning. Apabila ukuran sampah ada diatas $18 \mathrm{~cm}$, maka akan terdeteksi sebagai kosong dengan kondisi LED berwarna hijau.

\subsection{Skenario Pengujian DHT22}

Skenario pengujian Sensor DHT22 untuk mendeteksi kelembaban dalam tempat sampah yang dilakukan dengan menggunakan hygrometer sebagai penguji, hal ini untuk melihat respon output dari tempat sampah yang hasilnya dapat dilihat pada Tabel 8 .

Tabel 8. Skenario Pengujian Sensor DHT22

\begin{tabular}{|c|c|c|c|c|}
\hline $\begin{array}{c}\text { N } \\
\text { o }\end{array}$ & Nama Benda & $\begin{array}{c}\text { Nilai } \\
\text { Hygrom } \\
\text { eter }\end{array}$ & $\begin{array}{c}\text { Nilai } \\
\text { Sensor } \\
\text { DHT22 }\end{array}$ & $\begin{array}{c}\text { Respon Tempat } \\
\text { Sampah }\end{array}$ \\
\hline 1 & $\begin{array}{c}\text { Air biasa } \\
100 \mathrm{ml} \text { (tanpa } \\
\text { bungkus) }\end{array}$ & $59 \% \mathrm{RH}$ & $60 \% \mathrm{RH}$ & $\begin{array}{c}\text { LED merah } \\
\text { (bahaya), Buzzer } \\
\text { menyala }\end{array}$ \\
\hline 2 & $\begin{array}{c}\text { Es batu } 2 \text { pcs } \\
\text { (kecil) }\end{array}$ & $64 \% \mathrm{RH}$ & $64 \% \mathrm{RH}$ & $\begin{array}{c}\text { LED merah } \\
\text { (bahaya), Buzzer } \\
\text { menyala }\end{array}$ \\
\hline 4 & $\begin{array}{c}\text { Air biasa } \\
\text { (00ml (dalam } \\
\text { botol) }\end{array}$ & $57 \% \mathrm{RH}$ & $56 \% \mathrm{RH}$ & $\begin{array}{c}\text { LED hijau (tidak } \\
\text { berbahaya) }\end{array}$ \\
\hline 5 & $\begin{array}{c}\text { Kresek kecil } \\
\text { (dingin 1,5 } \\
\text { botol })\end{array}$ & $70 \% \mathrm{RH}$ & $70 \% \mathrm{RH}$ & $\begin{array}{c}\text { LED merah } \\
\text { (bahaya), Buzzer } \\
\text { menyala }\end{array}$ \\
\hline
\end{tabular}

Dari hasil pengujian pada Tabel 8 bisa diamati bahwa tempat sampah akan merespon apabila nilai sensor ada diatas 59\% RH dengan kondisi berbahaya dimana LED berwarna merah dan buzzer menyala. Jika dibawah 59\% RH maka dikondisikan sebagai kondisi tidak berbahaya, dan LED berwarna hijau.

\subsection{Skenario Pengujian Sensor MQ135}

Skenario pengujian Sensor MQ135 untuk mendeteksi asap dalam tempat sampah yang dilakukan dengan menggunakan Combustible Gas Detector 602 sebagai penguji, hal ini untuk melihat respon output dari tempat sampah yang hasilnya dapat dilihat pada Tabel 9.
Tabel 9. Skenario Pengujian Sensor MQ135

\begin{tabular}{|c|c|c|c|c|}
\hline No & $\begin{array}{l}\text { Nama } \\
\text { Benda }\end{array}$ & $\begin{array}{c}\text { Nilai } \\
\text { Combustible } \\
\text { Gas } \\
\text { Detector }\end{array}$ & $\begin{array}{c}\text { Nilai } \\
\text { Sensor } \\
\text { MQ135 }\end{array}$ & $\begin{array}{c}\text { Respon } \\
\text { Tempat } \\
\text { Sampah }\end{array}$ \\
\hline 1 & $\begin{array}{c}\text { Asap } \\
\text { kertas } \\
\text { dibakar }\end{array}$ & 160 ppm & $\begin{array}{c}161 \\
\mathrm{ppm}\end{array}$ & $\begin{array}{c}\text { LED } \\
\text { merah } \\
\text { (bahaya), } \\
\text { Buzzer } \\
\text { menyala }\end{array}$ \\
\hline 2 & $\begin{array}{c}\text { Asap } \\
\text { tissue } \\
\text { dibakar }\end{array}$ & $124 \mathrm{ppm}$ & $\begin{array}{c}127 \\
\mathrm{ppm}\end{array}$ & $\begin{array}{c}\text { LED } \\
\text { merah } \\
\text { (bahaya), } \\
\text { Buzzer } \\
\text { menyala }\end{array}$ \\
\hline 3 & $\begin{array}{l}\text { Asap } \\
\text { rokok }\end{array}$ & $169 \mathrm{ppm}$ & $\begin{array}{l}175 \\
\mathrm{ppm}\end{array}$ & $\begin{array}{c}\text { LED } \\
\text { merah } \\
\text { (bahaya), } \\
\text { Buzzer } \\
\text { menyala }\end{array}$ \\
\hline 4 & $\begin{array}{c}\text { Asap } \\
\text { kapas } \\
\text { dibakar }\end{array}$ & 100 ppm & $\begin{array}{c}103 \\
\text { ppm }\end{array}$ & $\begin{array}{c}\text { LED } \\
\text { hijau } \\
\text { (tidak } \\
\text { bahaya), } \\
\text { Buzzer } \\
\text { mati }\end{array}$ \\
\hline 5 & $\begin{array}{c}\text { Asap } \\
\text { plastik } \\
\text { dibakar }\end{array}$ & $92 \mathrm{ppm}$ & 93 ppm & $\begin{array}{c}\text { LED } \\
\text { hijau } \\
\text { (tidak } \\
\text { bahaya), } \\
\text { Buzzer } \\
\text { mati }\end{array}$ \\
\hline
\end{tabular}

Dari hasil pengujian pada Tabel 9 diamati bahwa tempat sampah akan merespon apabila nilai sensor ada diatas 120 ppm dengan kondisi berbahaya dimana LED berwarna merah dan buzzer menyala. Jika dibawah 120 ppm maka dikondisikan sebagai kondisi tidak berbahaya, dan LED berwarna hijau.

\subsection{Pengujian Tempat Sampah Pintar}

Pengujian semua sistem pada tempat sampah pintar dengan melakukan pengujian pada semua kinerja sistem yang ada baik kinerja komponen maupun kinerja dan eksekusi program yang telah dibuat.

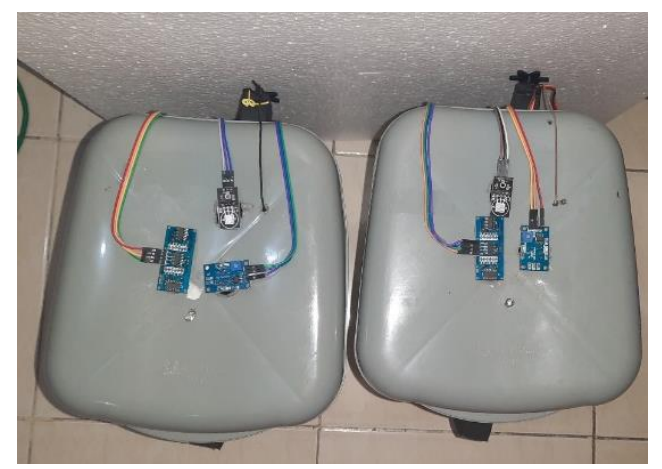

Gambar 4. Bentuk tempat sampah pintar bagian atas 
Terdiri dari sensor DHT11 untuk mengecek kelembaban, sensor ultrasonik untuk mengecek isi kapasitas tempat sampah, sensor MQ2 untuk medeteksi gas, dan LED.

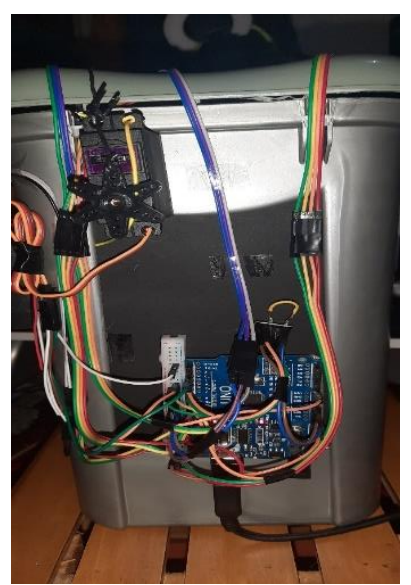

Gambar 5. Bentuk tempat sampah bagian belakang

Pada bagian belakang tempat sampah terdiri dari Arduino Uno, ESP8266, Motor Servo, Buzzer, dan Breadboard.

Pengujian pada fungsionalitas komponen pada tempat sampah pintar yang bisa dilihat pada Tabel 10 dibawah ini.

Tabel 10. Pengujian Fungsionalitas

\begin{tabular}{|c|c|c|c|c|c|}
\hline $\begin{array}{c}\text { N } \\
\text { o }\end{array}$ & $\begin{array}{c}\text { Nama } \\
\text { Kompo } \\
\text { nen }\end{array}$ & $\begin{array}{c}\text { Juml } \\
\text { ah } \\
\text { tiap 1 } \\
\text { temp } \\
\text { at } \\
\text { samp } \\
\text { ah }\end{array}$ & $\begin{array}{c}\text { Teganga } \\
\text { n yang } \\
\text { dibutuh } \\
\text { kan }\end{array}$ & $\begin{array}{c}\text { Berfun } \\
\text { gsi } \\
\text { dengan } \\
\text { baik }\end{array}$ & $\begin{array}{c}\text { Mempun } \\
\text { yai } \\
\text { Kendala } \\
/ \\
\text { Trouble }\end{array}$ \\
\hline 1 & $\begin{array}{c}\text { Sensor } \\
\text { DHT22 }\end{array}$ & 1 & $5 \mathrm{~V}$ & Ya & Tidak \\
\hline 2 & $\begin{array}{c}\text { Sensor } \\
\text { Ultrason } \\
\text { ik }\end{array}$ & 1 & $5 \mathrm{~V}$ & Ya & Tidak \\
\hline 3 & $\begin{array}{c}\text { Sensor } \\
\text { PIR }\end{array}$ & 1 & $5 \mathrm{~V}$ & Ya & Tidak \\
\hline 4 & $\begin{array}{c}\text { Sensor } \\
\text { MQ135 }\end{array}$ & 1 & $5 \mathrm{~V}$ & Ya & Tidak \\
\hline 5 & Buzzer & 1 & $5 \mathrm{~V}$ & Ya & Tidak \\
\hline 6 & $\begin{array}{c}\text { Motor } \\
\text { Servo }\end{array}$ & 1 & $12 \mathrm{~V}$ & Ya & Tidak \\
\hline 7 & $\begin{array}{c}\text { Arduino } \\
\text { Uno R3 }\end{array}$ & 1 & $5 \mathrm{~V}$ & Ya & Tidak \\
\hline 8 & $\begin{array}{c}\text { ESP826 } \\
6\end{array}$ & 1 & $3.3 \mathrm{~V}$ & Ya & Tidak \\
\hline 9 & $\begin{array}{c}\text { LED } \\
\text { RGB }\end{array}$ & 1 & $5 \mathrm{~V}$ & Ya & Tidak \\
\hline
\end{tabular}

\subsection{Tampilan Halaman Login}

Halaman login untuk masuk ke halaman utama sesuai dengan hak akses yang dimiliki. Hak akses ada 2, yaitu admin dan user. Tampilan halaman login bisa dilihat pada Gambar 6.

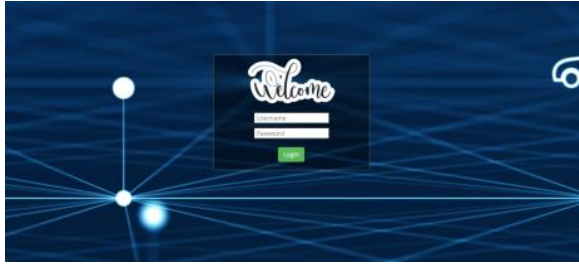

Gambar 6. Tampilan halaman utama

\subsection{Tampilan Halaman Utama Admin}

Pada halaman utama pada admin terdapat informasi mengenai kondisi tempat sampah seperti kelembaban, isi kapasitas, asap/gas, dan tutup tempat sampah. Pada halaman untuk admin terdapat tab Home, Tables, Register, dan Logout. Tampilan Halaman utama pada admin bisa dilihat pada Gambar 7.

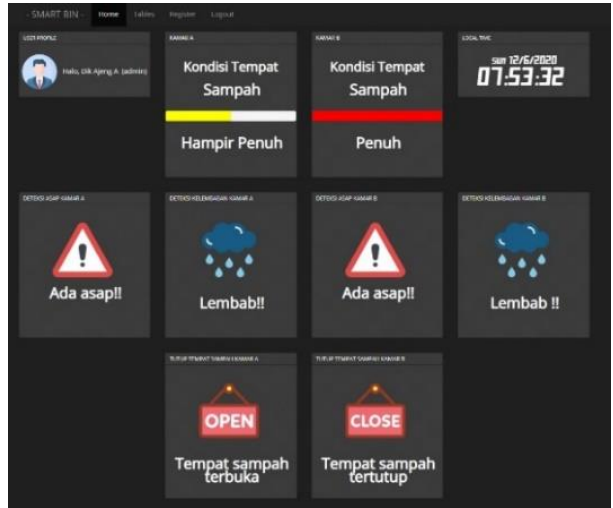

Gambar 7. Tampilan Halaman Utama Admin

\subsection{Tampilan Halaman Utama User}

Pada halaman utama pada user terdapat informasi mengenai kondisi tempat sampah seperti kelembaban, isi kapasitas, asap/gas, dan tutup tempat sampah. Pada halaman untuk admin terdapat tab Homes dan Logout. Tampilan Halaman utama pada user bisa dilihat pada Gambar 8.

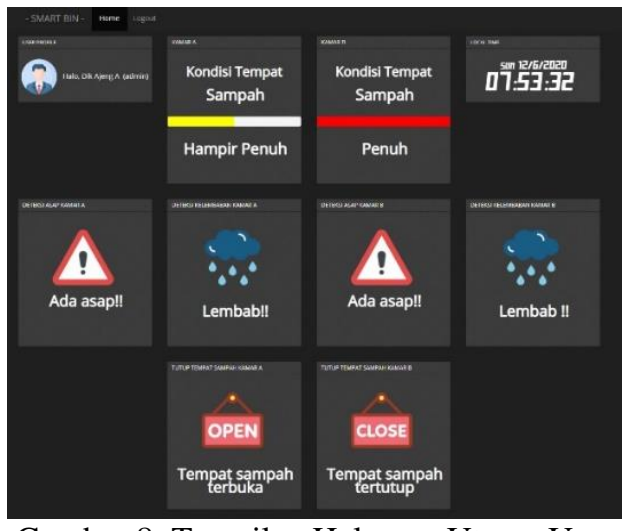

Gambar 8. Tampilan Halaman Utama User

\subsection{Tampilan Halaman Tabel Data}

Pada halaman grafik terdapat informasi mengenai kondisi tempat sampah seperti status tutup tempat sampah, status isi sampah, status kelembaban, dan status deteksi asap berdasarkan tanggal dan waktu dalam bentuk grafik 
time series. Tampilan halaman grafik bisa dilihat pada Gambar 9.

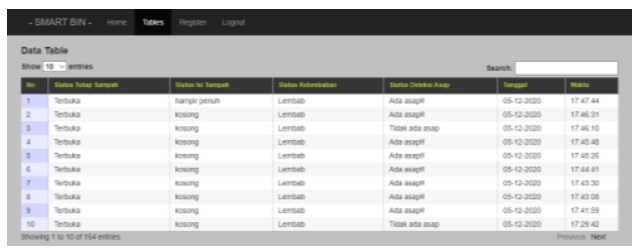

Gambar 9. Tampilan Halaman Tabel Data

\subsection{Tampilan Halaman Grafik}

Pada halaman tabel data terdapat informasi mengenai kondisi tempat sampah seperti status tutup tempat sampah, status isi sampah, status kelembaban, status deteksi asap, tanggal, dan waktu. Tampilan Halaman tabel data bisa dilihat pada Gambar 10.

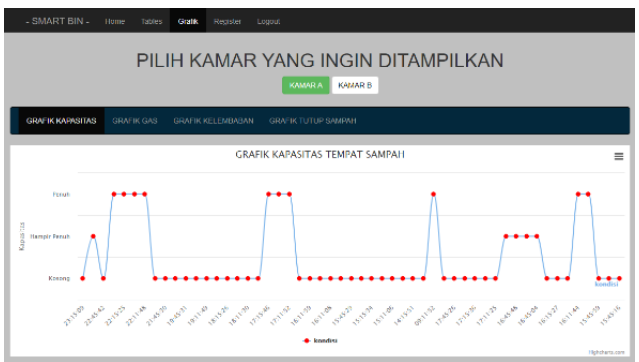

Gambar 10. Tampilan Halaman Grafik

\subsection{Tampilan Halaman Register}

Pada halaman register untuk menambahkan akun pada database. Tampilan Halaman Register bisa dilihat pada Gambar 11.

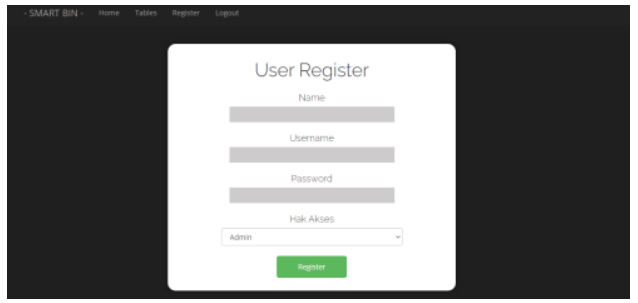

Gambar 11. Tampilan Halaman Register

\subsection{Tampilan Notifikasi Pada Telegram}

Pada kondisi ketika tempat sampah penuh, terdeteksi gas, dan terdeteksi sampah lembab akan muncul tampilan notifikasi pada telegram. Tampilan notifikasi pada telegram bisa dilihat pada Gambar 12.

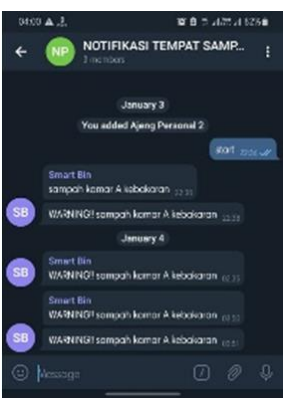

Gambar 12. Tampilan Notifikasi Telegram

\subsection{Pengujian Terhadap User}

Pengujian yang ditujukan kepada user bertujuan untuk melihat kelayakan dari aplikasi yang telah dibuat. Pengujian ini dilakukan secara objektif, dimana dilakukan pengujian aplikasi secara langsung, dengan membuat sebuah kuisoner yang ditujukan kepada user sebagai pengguna aplikasi sistem monitoring tempat sampah pintar. Dengan demikian kuisoner yang dibuat untuk melakukan pengujian disebar kepada 10 orang responden, berikut pengujan yang dilakukan kepada user dapat dilihat pada Tabel 11.

Tabel 11. Pengujian Terhadap User

\begin{tabular}{|c|c|c|c|c|c|}
\hline \multirow[b]{2}{*}{ No } & \multirow[b]{2}{*}{ Pertanyaan } & \multicolumn{4}{|c|}{ Jawaban } \\
\hline & & $\begin{array}{l}\text { Sangat } \\
\text { Setuju }\end{array}$ & Setuju & $\begin{array}{l}\text { Kurang } \\
\text { Setuju }\end{array}$ & $\begin{array}{l}\text { Tidak } \\
\text { Setuju }\end{array}$ \\
\hline 1 & $\begin{array}{c}\text { Apakah } \\
\text { website } \\
\text { halamannya } \\
\text { mudah untuk } \\
\text { dipahami? }\end{array}$ & 3 & 7 & & \\
\hline 2 & $\begin{array}{c}\text { Apakah } \\
\text { tampilan } \\
\text { halaman } \\
\text { website } \\
\text { sudah cukup } \\
\text { menarik bagi } \\
\text { user? }\end{array}$ & 4 & 5 & 1 & \\
\hline 3 & $\begin{array}{c}\text { Apakah } \\
\text { system } \\
\text { monitoring } \\
\text { ini dapat } \\
\text { memudahkan } \\
\text { anda dalam } \\
\text { memantau } \\
\text { kondisi } \\
\text { tempat } \\
\text { sampah? } \\
\end{array}$ & 3 & 7 & & \\
\hline 4 & $\begin{array}{c}\text { Apakah } \\
\text { system yang } \\
\text { digunakan } \\
\text { dapat } \\
\text { berjalan } \\
\text { secara real- } \\
\text { time? }\end{array}$ & 2 & 7 & 1 & \\
\hline 5 & $\begin{array}{c}\text { Apakah } \\
\text { sistem yang } \\
\text { digunakan } \\
\text { oleh system } \\
\text { monitoring } \\
\text { tempat } \\
\text { sampah } \\
\text { sudah } \\
\text { akurat? }\end{array}$ & 1 & 8 & 1 & \\
\hline & Total & 13 & 34 & 3 & 0 \\
\hline
\end{tabular}

Jumlah pertanyaan : 5

Jumlah user $\quad: 10$

Faktor pembagi $: 5 * 10=50$

1. Presentase user memilih sangat setuju $(13 / 50 * 100 \%)=26 \%$

2. Presentase user memilih setuju 
$(34 / 50 * 100 \%)=68 \%$

3. Presentase user memilih kurang setuju $(3 / 50 * 100 \%)=6 \%$

4. Presentase user memilih tidak setuju $(0 / 50 * 100 \%)=0 \%$

Dari pengujian yang ditujukan kepada 10 user maka didapatkan hasil yang menunjukan bahawa $26 \%$ menyatakan sangat setuju, 68\% menyatakan setuju, 6\% menyatakan kurang setuju dan $0 \%$ menyatakan tidak setuju.

\subsection{Pengujian Software}

Pengujian software pada penelitian ini dengan dilakukannya menguji kompabilitas website menggunakan metode black box. Hasil uji coba kompabilitas website terhadap web browser seperti ditunjukan pada tabel dibawah ini.

Tabel 12. Pengujian Software

\begin{tabular}{|c|c|c|c|c|}
\hline \multirow{2}{*}{ No } & $\begin{array}{c}\text { Aspek } \\
\text { Pengujian }\end{array}$ & Opera & Chrome & $\begin{array}{c}\text { Microsoft } \\
\text { Edge }\end{array}$ \\
\cline { 3 - 5 } 1 & $\begin{array}{c}\text { Halaman } \\
\text { Login }\end{array}$ & Ya & Ya & Ya \\
\hline 2 & $\begin{array}{c}\text { Halaman } \\
\text { Utama Admin }\end{array}$ & Ya & Ya & Ya \\
\hline 3 & $\begin{array}{c}\text { Halaman } \\
\text { Utama User }\end{array}$ & Ya & Ya & Ya \\
\hline 4 & $\begin{array}{c}\text { Halaman } \\
\text { Tabel Data }\end{array}$ & Ya & Ya & Ya \\
\hline 5 & $\begin{array}{c}\text { Halaman } \\
\text { Grafik Data }\end{array}$ & Ya & Ya & Ya \\
\hline 6 & $\begin{array}{c}\text { Halaman } \\
\text { Register }\end{array}$ & Ya & Ya & Ya \\
\hline 7 & $\begin{array}{c}\text { Halaman } \\
\text { Logout Admin }\end{array}$ & Ya & Ya & Ya \\
\hline 8 & $\begin{array}{c}\text { Halaman } \\
\text { Logout User }\end{array}$ & Ya & Ya & Ya \\
\hline
\end{tabular}

\section{KESIMPULAN DAN SARAN}

\subsection{Kesimpulan}

Dari beberapa tahap pengujian dan perbandingan yang telah dilakukan, menghasilkan beberapa kesimpulan diantaranya :

1. Kondisi menentukan isi kapasitas berdasarkan tinggi isi tempat sampah berpengaruh pada presentase error. Pengaruhnya bisa dalam kondisi bentuk dari objek tersebut, posisi dari objek tersebut, dan ukuran dari objek tersebut.

2. Hasil skenario pengujian sensor infrared pada Tabel 6 bahwa dapat mendeteksi objek pada range $4 \mathrm{~cm}$ sampai $17 \mathrm{~cm}$ dimana kondisi tutup tempat sampah akan terbuka.

3. Hasil skenario pengujian sensor ultrasonik pada Tabel 7 bahwa kondisi dibawah $5 \mathrm{~cm}$ terdeteksi penuh, diantara $6-17 \mathrm{~cm}$ terdeteksi hampir penuh, dan diatas $18 \mathrm{~cm}$ itu kosong.

4. Hasil skenario pengujian DHT22 pada Tabel 8 apabila nilai sensor diatas $59 \% \mathrm{RH}$ akan terdeteksi bahaya, jika dibawah itu tidak terdeteksi bahaya.
5. Hasil skenario pengujian MQ135 pada Tabel 9 apabila nilai sensor diatas 120 ppm akan terdeteksi bahaya, jika dibawah itu tidak terdeteksi bahaya.

6. Website berjalan dengan baik pada beberapa web browser seperti Opera, Microsoft Edge, dan Google Chrome karena aplikasi menggunakan PHP dan Bootstrap sebagai tampilan front-end.

\subsection{Saran}

Agar dalam aplikasi ini berjalan dengan baik kedepannya, maka ada beberapa hal yang perlu dilakukan yaitu sebagai berikut :

1. Sistem tempat sampah pintar sebaiknya memiliki kondisi yang lebih akurat dalam mendeteksi isi tempat sampah. Bisa menggunakan berat benda, atau yang lainnya.

2. Sistem tempat sampah pintar ini memiliki desain yang masih rentan akan jenis sampah yang terlalu lembab. Sehingga kedepannya bisa merancang desain yang lebih minimalis juga aman bagi komponen yang digunakan.

3. Sistem tempat sampah pintar menggunakan notifikasi ke Telegram. Kedepannya bisa ditambahkan dengan notifikasi ke Whatsapp atau social media lainnya

\section{DAFTAR PUSTAKA}

[1] Prayitno, W. A., Muttaqin, A., \& Syauqy, D. (2017). Sistem Monitoring Suhu, Kelembaban, dan Pengendali Penyiraman Tanaman Hidroponik menggunakan Blynk Android. Jurnal Pengembangan Teknologi Informasi dan Ilmu Komputer e-ISSN, 2548, 964X.

[2] Astutik, R. P. (2019). APLIKASI TELEGRAM UNTUK SISTEM MONITORING PADA SMART FARMING: TELEGRAM APPLICATION MONITORING SYSTEM FOR SMART FARMING. Jurnal Teknologi dan Terapan Bisnis, 2(1), 1-6.

[3] Rahardja, U., Aini, Q., \& Khoirunisa, A. (2019). Monitoring Kinerja User Akuntan Menggunakan Dashboard Pada Web Based Accounting Online di Perguruan Tinggi. Sains dan Teknologi Informasi, 4(2), 58-62.

[4] Susanti, E., Triyono, J., \& Pi, R. (2016). Pengembangan sistem pemantau dan pengendali kendaraan menggunakan raspberry pi dan firebase. Jurnal Informatika, 1, 144-153.

[5] Waker, I. M. S. (2019). Perencanaan Pengelolaan Sampah Kampus I Institut Teknologi Nasional Malang (Doctoral dissertation, ITN Malang).

[6] Putra, A. P. P., Wibowo, S. A., \& Pranoto, Y. A. (2020). PENERAPAN SISTEM MONITORING HEALTHY SMART HOME DENGAN EARLY WARNING SYSTEM. JATI (Jurnal Mahasiswa Teknik Informatika), 4(2), 58-64. 
[7] Kurnianto, D., Hadi, A. M., \& Wahyudi, E. (2016). Perancangan Sistem Kendali Otomatis Pada Smart Home Menggunakan Modul Arduino Uno. Jurnal Nasional Teknik Elektro, 5(2), 260-270.

[8] Hardyanto, R. H. (2017). Konsep Internet of Things pada Pembelajaran Berbasis Web. Jurnal Dinamika Informatika, 6(1), 87-97.

[9] Kustanti, I., Muslim, M. A., \& Yudaningtyas, E. (2016). Pengendalian Kadar Keasaman (pH) Pada Sistem Hidroponik Stroberi Menggunakan Kontroler PID Berbasis Arduino Uno. Jurnal Mahasiswa TEUB, 2(1).

[10] Putra, I. G. P. M. E., \& Darminta, I. K. (2017, November). Monitoring Penggunaan Daya Listrik Sebagai Implementasi Internet of Things Berbasis ESP8266. In Prosiding Sentrinov (Seminar Nasional Terapan Riset Inovatif) (Vol. 3, No. 1, pp. TE313-TE327).

[11] Yudha, P. S. F., \& Sani, R. A. (2019). Implementasi Sensor Ultrasonik Hc-Sr04 Sebagai Sensor Parkir Mobil Berbasis Arduino. EINSTEIN (e-Journal), 5(3).

[12] Saing, L., \& Hernawan, A. (2019). Rancang Bangun Alat Monitoring Detak Jantung
Berbasis IOT (Internet Of Things) (Doctoral dissertation, University of Technology Yogyakarta).

[13] PERDANA, R. (2019). RANCANG BANGUN ALAT PENDETEKSI KEBERADAAN MANUSIA DEWASA DI HUTAN MENGGUNAKAN SENSOR PIR, DRONE DAN ARDUINO UNO R3. Jurnal Online Mahasiswa (JOM) Bidang Teknik Elektro, 1(1).

[14] Budi, K. S., \& Pramudya, Y. (2017, October). Pengembangan Sistem Akuisisi Data Kelembaban dan Suhu Dengan Menggunakan SENSOR DHT11 dan Arduino Berbasis IOT. In Prosiding Seminar Nasional Fisika (E-Journal) (Vol. 6, pp. SNF2017-CIP).

[15] Rosa, A. A., Simon, B. A., \& Lieanto, K. S. (2020). Sistem Pendeteksi Pencemaran Udara Portabel Menggunakan Sensor MQ-7 dan MQ135. Ultima Computing: Jurnal Sistem Komputer, 12(1), 23-28.

[16] Saleh, M., \& Haryanti, M. (2017). Rancang Bangun Sistem Keamanan Rumah Menggunakan Relay. Jurnal Teknologi Elektro, $8(2)$. 